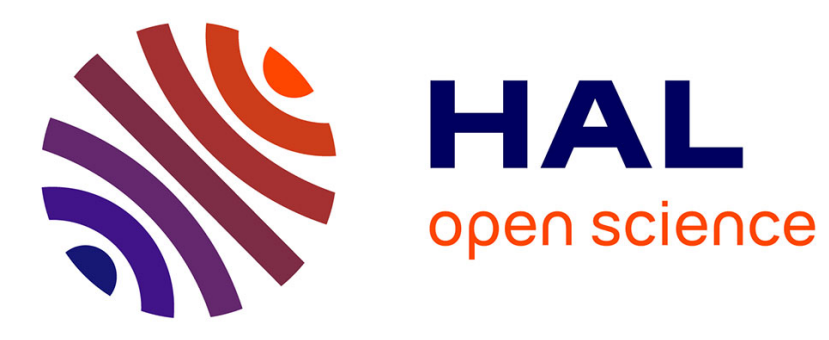

\title{
The role of the mealybug Phenacoccus aceris in the spread of Grapevine leafroll-associated virus -1 (GLRaV-1) in two French vineyards
}

Jean Le Maguet, Jean-Jacques Fuchs, Joel J. Chadoeuf, Monique M. Beuve, Etienne E. Herrbach, Olivier O. Lemaire

\section{To cite this version:}

Jean Le Maguet, Jean-Jacques Fuchs, Joel J. Chadoeuf, Monique M. Beuve, Etienne E. Herrbach, et al.. The role of the mealybug Phenacoccus aceris in the spread of Grapevine leafroll-associated virus -1 (GLRaV-1) in two French vineyards. European Journal of Plant Pathology, 2013, 135, pp.415-427. 10.1007/s10658-012-0099-x . hal-02651362

\section{HAL Id: hal-02651362 \\ https://hal.inrae.fr/hal-02651362}

Submitted on 29 May 2020

HAL is a multi-disciplinary open access archive for the deposit and dissemination of scientific research documents, whether they are published or not. The documents may come from teaching and research institutions in France or abroad, or from public or private research centers.
L'archive ouverte pluridisciplinaire HAL, est destinée au dépôt et à la diffusion de documents scientifiques de niveau recherche, publiés ou non, émanant des établissements d'enseignement et de recherche français ou étrangers, des laboratoires publics ou privés. 


\title{
The role of the mealybug Phenacoccus aceris in the spread of Grapevine leafroll-associated virus -1 (GLRaV-1) in two French vineyards
}

\author{
Jean Le Maguet • Jean-Jacques Fuchs • \\ Joël Chadœuf • Monique Beuve • \\ Etienne Herrbach • Olivier Lemaire
}

Accepted: 10 September 2012 /Published online: 26 September 2012

(C) KNPV 2012

\begin{abstract}
Spread patterns of a Grapevine leafrollassociated virus 1 (GLRaV-1) epidemic and a mealybug infestation survey over 10 year were recorded in two Burgundy French vineyards to investigate the relation between them. The temporal evolution of leafroll spread at both study sites was compared on disease incidence data with logistic regression models. We first tested if the spatial distribution of the disease and the mealybug were aggregated using permutation methods, then we tested the independence between the two spatial patterns by randomly shifting one pattern. In Bon-
\end{abstract}

Electronic supplementary material The online version of this article (doi:10.1007/s10658-012-0099-x) contains supplementary material, which is available to authorized users.

J. Le Maguet $\cdot$ M. Beuve · E. Herrbach • O. Lemaire INRA UMR 1131 Santé de la Vigne et Qualité du Vin, 68000 Colmar, France

J. Le Maguet

Comité Interprofessionnel du Vin de Champagne (CIVC), 51200 Epernay, France

J. Le Maguet $(\bowtie) \cdot$ J.J. Fuchs $\cdot$ M. Beuve $\cdot$ E. Herrbach •

O. Lemaire

Université de Strasbourg (UDS),

67000 Strasbourg, France

e-mail: jean.le-maguet@colmar.inra.fr

J. Chadœuf

INRA UR 546 Biostatistique et Processus Spatiaux, 84914 Avignon, France zon, an increase from $5 \%$ to $86 \%$ of leafroll prevalence was observed over an 8-year time span, whereas leafroll prevalence remained stable around $5 \%$ in Marsannay-la-Côte during the same period. In Bonzon, the disease spread rapidly from older neighbouring vineyards in four main patches while no spread of the disease was recorded from infected vines in Marsannay-la-Côte. The mealybug Phenacoccus aceris was recorded on $74 \%$ of vines in Bonzon throughout the study and only $6 \%$ of vines in Marsannay-la-Côte. In the latter location, the disease was not associated with the presence of the mealybug, so that it may have arisen from infected plant material escaping the sanitary inspection. In Bonzon, the significant statistical correlation between the mealybug distribution and diseased plants suggests that $P$. aceris was responsible for the rapid spread of GLRaV-1 in the vineyard. This is the first report of GLRaV-1 natural spread in Europe.

Keywords Epidemiology · Ampelovirus · Grapevine scale insects $\cdot$ Leafroll disease $\cdot$ Spatial statistics
Abbreviations
GLRaV
Grapevine leafroll-associated virus
GVA
Grapevine virus A
GVB
Grapevine virus B
DAS-ELISA enzyme-linked immunosorbent assay 


\section{Introduction}

Grapevine leafroll disease is considered one of the most economically important virus diseases of wine grapes in many vine-growing regions around the world (Martelli and Boudon-Padieu 2006). It negatively impacts yield by delaying ripening of berries, the yield losses being estimated between 740 and $1200 € /$ ha per year, according to Atallah et al. 2012. Leafroll disease alters photosynthetic activity (Komar et al. 2010) and affects plant growth and longevity (Bertamini et al. 2004), lowers sugar content and phenolic compounds in berries, and increases acidity of must (Lee and Martin 2009). All Vitis vinifera varieties are susceptible to leafroll infection. If American rootstocks remain asymptomatic, diseased vines show highly variable symptom patterns according to cultivars, virus strains, and climatic conditions (Boudon-Padieu et al. 2000). These foliar symptoms, consisting of a strong reddening of the leaf blade, are easy to identify on red-cultivars such as Pinot noir and Cabernet franc. These discolourations are followed in late summer by downward rolling of leaf-margins and increase of leaf thickness (Martelli and Boudon-Padieu 2006). This disease is caused by distinct phloem-limited grapevine leafroll-associated viruses (GLRaVs), all members of the family Closteroviridae. Most leafroll viruses (GLRaV-1, -3, -4, -5, -6, -9, -Pr, -De, and GLRaCV) belong to the Ampelovirus genus whereas GLRaV-2 is a Closterovirus and GLRaV-7 has been lately assigned to a new tentative genus, phylogenetically close to Crinivirus (Al Rwahnih et al. 2012). Among leafroll viruses, GLRaV-3 is the most widespread especially in Mediterranean areas and most epidemiological studies have been conducted on this species (Cabaleiro and Segura 2006; Pietersen 2006; Golino et al. 2008). However, natural spread of leafroll has also been described for GLRaV-9 in Australia (Habili et al. 2003) and for GLRaV-1 in New-Zealand (Bonfiglioli et al. 2001).

The worldwide expansion of this disease is mainly attributed to the exchange of infected plant material, especially asymptomatic rootstocks (Cabaleiro and Segura 1997), since grapevine leafroll viruses are graft-transmissible and persist in propagative material (budwood, rootstocks, and grafted vines). However, natural spread of leafroll in vineyards has also been described in many regions where studies revealed a continual increase in the incidence of leafroll (Habili et al. 2003; Cabaleiro et al. 2008; Golino et al. 2008; Jooste et al. 2011). In Yugoslavia, Dimitrijevic reported for the first time in 1973 the natural spread of leafroll in a vineyard over a 3-year period. Further evidence of natural spread was obtained in 1985 in South Africa in a plot where leafroll-infected vines were randomly interplanted with healthy LN33 indicator vines (Engelbrecht and Kasdorf 1985). Since then, leafroll disease spread has been described in many vine-growing regions worldwide.

The first evidence of GLRaV transmission by scale insects (Hemiptera, Coccoidea) was obtained in 1990 in controlled laboratory experiments (Engelbrecht and Kasdorf 1990). Since then, many species of soft scales (Coccidae) and mealybugs (Pseudococcidae) have been shown to transmit grapevine ampeloviruses and vitiviruses (Belli et al. 1994; Sforza et al. 2003; Zorloni et al. 2006; Mahfoudhi et al. 2009; Le Maguet et al. 2012). In France, GLRaV-1, -2 , and -3 have been reported in naturally infected vineyards (Boudon-Padieu et al. 2000) and nine scale insect species have been commonly reported on grapevine: the soft scales Neopulvinaria innumerabilis, Parthenolecanium corni, Parthenolecanium persicae, Pulvinaria vitis (Coccidae), the armoured scale Targionia vitis (Diaspididae), and the mealybugs Heliococcus bohemicus, Phenacoccus aceris, Planococcus citri, and Planococcus ficus (Pseudococcidae) (Sforza 2008). Seven of these species have been shown to transmit one or more leafroll viruses efficiently (Belli et al. 1994; Cabaleiro and Segura 1997; Fortusini et al. 1997; Sforza et al. 2003; Zorloni et al. 2006; Mahfoudhi et al. 2009; Le Maguet et al. 2012). Among them, P. aceris is regularly mentioned as infesting vineyards and apple orchards in northeastern France (Le Maguet et al. 2010). Recently, laboratory experiments showed that $P$. aceris is a particularly efficient vector, being able to transmit at least eight viruses to grapevine (Le Maguet et al. 2012).

Most of epidemiological observations done in vineyards worldwide have focused on the complex Planococcus sp./GLRaV-3 under Mediterranean-type climate. However, P. aceris is also a widely distributed mealybug, commonly reported on a wide range of perennial hosts in Holarctic regions. Under continental climate, adult females of $P$. aceris appear in late spring and lay numerous eggs in a cottony egg sac under bark of the host plant species, especially grapevine, and constitute so a good candidate for leafroll disease transmission. In fact, $P$. aceris is 
suspected to play a major role in the natural spread of leafroll in vineyards (Sforza et al. 2003) but no long-term study has been made to explore leafroll epidemiology in relation with mealybug infestation. Among the four scale insect species identified on grapevine during monitoring of vineyards in northeastern France, $P$. aceris was widespread but its abundance and spatial distribution varied significantly between study sites (Le Maguet et al. 2010).

Patterns of leafroll distribution and spread have been well documented in vine growing regions through symptom surveys and spatial analyses (Cabaleiro et al. 2008; Golino et al. 2008; Jooste et al. 2011). The role of mealybugs in the spread of leafroll has been reported in such studies, but no statistical analysis has been performed to demonstrate the spatial correlation between mealybug infestation and leafroll spread in the studied plots.

The aim of this work is thus to assess the role of $P$. aceris in the spread of leafroll disease in vineyards. To this end, a 10-year survey was conducted on two vineyards infected by GLRaV-1 and infested by $P$. aceris in a semi-continental region of France, Burgundy. Complementary to the Planococcus sp./GLRaV-3 complex, it is the first long-term comprehensive research relating incidence of leafroll disease with the spatial patterns and ecology of a mealybug in vineyards.

\section{Materials and methods}

\section{Study sites}

The vineyard plots at the villages of Bonzon and Marsannay-la-Côte were monitored for leafroll prevalence and P. aceris presence (Fig. 1). The Bonzon plot was planted between two older vineyards in 2001 (GPS: 46.477400N, 4.777722W, Burgundy, France) with virus-free certified scions of cv Pinot noir (2758 plants in 18 rows). Leafroll symptoms were first noticed in 2003 on five plants, and GLRaV-1 was then confirmed by double-antibody sandwich enzyme-linked immunosorbent assay (DAS-ELISA). The Marsannay-la-Côte plot was planted in 1997 (GPS: 47.265726N, 4.978437W, Burgundy, France), with 2435 vines of cv Pinot noir, in 33 rows. The first leafroll symptoms were recorded in 1998 and confirmed by DAS-ELISA testing as GLRaV-1.
Leafroll monitoring

\section{Symptom marking}

Leafroll disease symptoms were monitored on each vine in both study sites every year from 2004 to 2011 in autumn between mid-September and mid-October before frost in order to compare the temporal dynamics. Symptom severity was ranked from 0 to 3 as follows: 0 for no leafroll symptoms; 1 for some lower leaves with reddish spots; 2 for most lower leaves being reddish, gradual reddening of leaves along branches; 3 for most or all leaves being deep red or purple, thick and brittle leaf blades, vines severely diseased. In Bonzon, vines of the two contiguous plots were also monitored in 2008 for leafroll symptom expression. All data were recorded on xy matrices for further mapping on grids and spatial analysis. The presence of GLRaV-1 was ascertained in winter 2006-2007 by DAS-ELISA for both study sites in a biotine-streptavidine procedure (Zimmermann et al. 1990). The sampling method was to collect one vine of every four along the row, regardless of previous visible symptoms. Tests were made on woody slices taken from three lignified canes from a total of 689 plants in Bonzon and 607 plants in Marsannay-la-Côte.

\section{Temporal analysis of leafroll spread}

The temporal disease progress was analyzed using previously tested methods (Habili and Nutter 1997; Pietersen 2006). The annual incidence of leafroll was estimated for both study sites by annual symptom data. Changes in the leafroll incidence (progression rate of newly diseased vines each year) with the change in time $(d y / d t$ versus $t)$ were plotted as rate curves. The incidence of leafroll was linearized using a logistic regression model to study the relationship between leafroll incidence and time.

Mealybug monitoring

The presence of $P$. aceris was studied from 2006 to 2009 in both study sites. Mealybug populations were counted in spring between the last week of April and the second week of May during their emergence period. Mealybug presence was systematically checked on buds, young leaves, canes, and vine stock according to a 5-min count time per vine. The data obtained were recorded on an xy matrix system for further mapping 
Fig. 1 a Geographical location of the two study sites in France and Burgundy and $\mathbf{b}$ schematic representation of the plots with row orientation

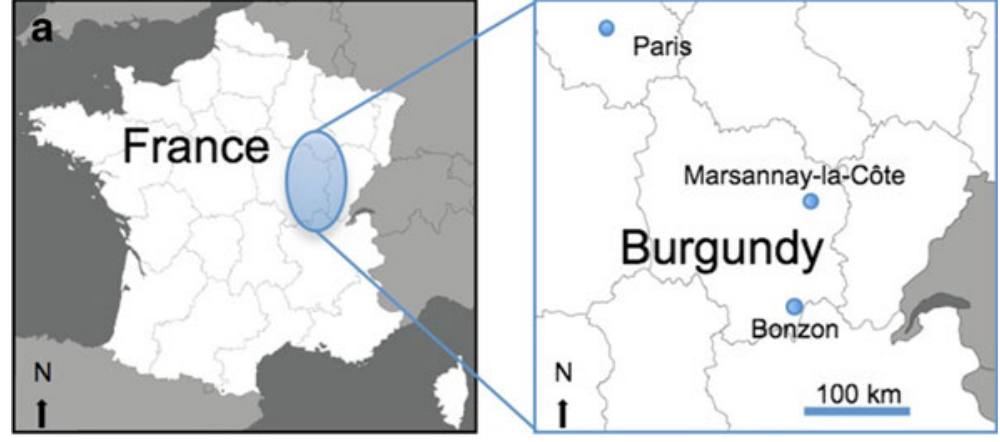

b

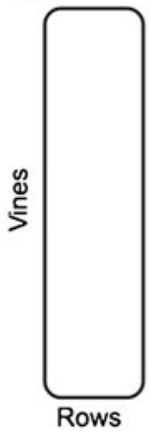

Bonzon and spatial analysis. The numbers of $P$. aceris present on each vine from 2006 to 2009 were converted for both study sites into 3-D charts.

Statistical analysis of the spatio-temporal dynamics of leafroll distribution

\section{Statistical tool}

Analyses were conducted using procedures designed previously (Peyrard et al. 2005) and running on R free software (Version 2.13.0, R Development Core Team 2011). Monte Carlo tests were conducted to study leafroll distribution and its spatial correlation with that of $P$. aceris according the method described by Peyrard et al. (2006). Each test was performed with 200 permutations for distances $d=20$. For all tests, each permutation data set was tested for the independence hypothesis $\mathrm{H}_{0}$ : the symptomatic vines are independently and identically distributed (i.i.d.). The statistical assessment of the spatial dependency provided a variogram, which was compared to a confidence interval constructed from test statistics of the random permutation of all the data (Gaetan and Guyon 2008). The $\mathrm{H}_{0}$ hypothesis of each test was rejected when the variogram or the covariogram was outside the confidence interval delimited by Monte Carlo confidence levels of $2.5 \%$ and $97.5 \%$ obtained under the independence assumption.

\section{Strategy of analysis}

Three main steps used in the statistical analysis were applied for each year and at both study sites. (i) The global independence of the distribution of diseased vines was tested according to several matrices: presence or absence of leafroll symptoms, severity grade and newly symptomatic vines. Tests of independence between and within rows were then performed to analyze whether the dependence between data was favoured rather along the lines or along the rows of the study plot (Gaetan and Guyon 2008). A test of global independence was also applied to study leafroll distribution in Bonzon and its two contiguous vineyards using symptom notations recorded in 2008. (ii) The global independence of the distribution of $P$. aceris-infested vines was then studied based on the presence/absence matrixes. (iii) Finally, we studied, the spatial dependency of leafroll diseased areas with $P$. aceris-infested areas. The dependency between distribution patterns was tested with permutations by translation and assessed by a covariogram (Peyrard 
et al. 2005). Since the analysis generated more graphs than we can include here, only a few selected graphs are displayed in the following analysis (the entire set of graphs is available upon request).

\section{Results}

Temporal analysis of leafroll spread

The temporal evolution in leafroll incidence was different between the two vineyards. In Bonzon, a sigmoid curve showed that the percentage of vines exhibiting leafroll symptoms increased constantly from $5 \%$ in 2004 to $86 \%$ in 2011 (Fig. 2a).

Fig. 2 Spread of grapevine leafroll disease in studied sites between 2004 and 2011. a Disease progress curve of leafroll disease based on the annual percentages of symptomatic vines; b Curve of incidence of leafroll function of time; $\mathbf{c}$ Logit of leafroll disease incidence versus time. The slope of the regression lines corresponds to the rate of leafroll spread in each plot, respectively 0.76 logit/year and 0.05 logit/year in Bonzon and Marsannay-la-Côte
Conversely, the incidence of leafroll in Marsannayla-Côte remained stable at around $5 \%$ throughout the study, even though a slight increase of symptomatic vines, up to $9 \%$, was noticed there in 2011. The presence of GLRaV-1 was determined during the winter of 2006-2007 by DAS-ELISA in Bonzon and Marsannay-la-Côte. The serological detection of virus during the vegetative dormancy of vines gave information about the symptom expression latency. In Bonzon, the proportion of positive vines $(20 \%)$ was between the percentages of symptomatic vines in autumn 2006 and 2007 (13\% and $28 \%$ respectively). Conversely, $9 \%$ of GLRaV-1 positive vines were found in Marsannay-la-Côte whereas symptom prevalence was around $4 \%$ in 2006 and 2007. This showed
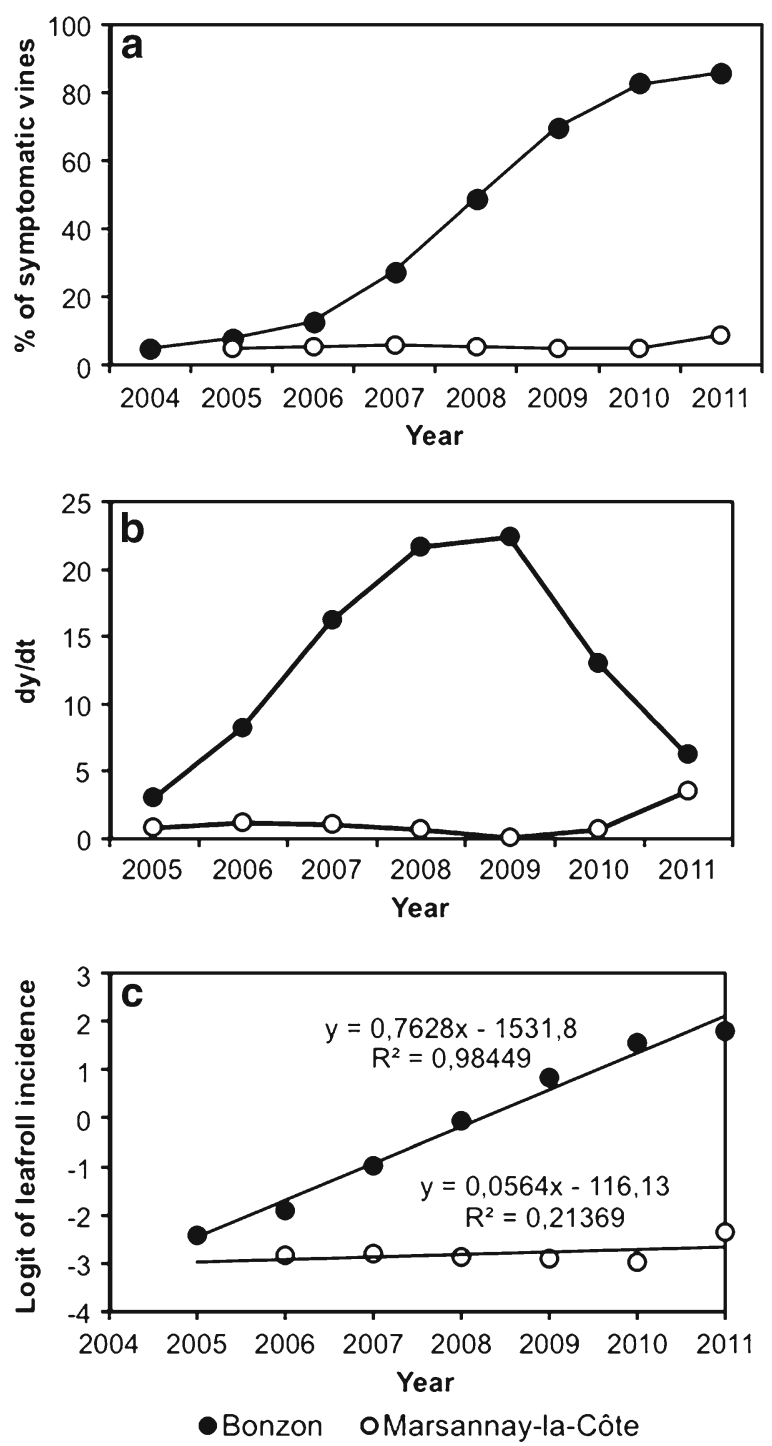
for both study sites that about $5 \%$ of vines were infected in 2006, but remained symptomless.

The absolute rate curves ( $d y / d t$ versus $t)$ show the instantaneous changes of the disease incidence (Fig. 2b). For Bonzon, the curve is typically parabolic and shows that the incidence of leafroll increased for 4 years to reach a plateau: the rate of incidence was the highest in 2008 and 2009 with over $20 \%$ of newly infected vines per year. Then the $d y / d t$ rate decreased as the proportion of new diseased vines decreased. For Marsannay-laCôte, the $d y / d t$ curve indicates that leafroll incidence remained stable throughout the study except in 2011 when 98 additional plants expressed symptoms compared with 2010. The logistic regression model confirmed the two different temporal leafroll patterns (Fig. 2c). The estimated infection rate obtained for Bonzon was very high (0.76 logit units/year) compared to that obtained in Marsannay-la-Côte (0.05 logit units/ year). The rapid spread of the disease is attested in Bonzon by the significant value of the determination coefficient of the logistic model $\left(R^{2}=0.98\right)$.

Temporal analysis of the mealybug distribution

In Bonzon, young adult females of $P$. aceris were observed on stems, buds, and under vine bark. Conversely, since no adult females of $P$. aceris were observed in spring on vines in Marsannay-la-Côte, monitoring was repeated in summer, which enabled the detection of the first instar nymphs (crawlers) on vine leaves.

Depending on the year, from $35 \%$ to $44 \%$ of vines harboured at least one mealybug in Bonzon, and from $1 \%$ to $7 \%$ in Marsannay-la-Côte, but with no significant fluctuation of $P$. aceris population at both sites throughout the monitoring period. The overall proportion of vines observed at least once with $P$. aceris was greater in Bonzon (74\%) than in Marsannay-la-Côte (8\%). Furthermore, populations observed on each vine were much higher in Bonzon: there were more than 15 young adult females per vine in Bonzon compared to fewer than six crawlers per vine in Marsannay-la-Côte.

Statistical analysis of the spatio-temporal dynamics of leafroll and mealybug

\section{Analysis of leafroll symptoms distribution}

The annual distribution of symptomatic vines is represented on grids where each square corresponds to a single plant. The grids confirmed the two distinct temporal patterns described above. Fig. 3 displays eight successive maps showing that leafroll spread rapidly throughout the Bonzon plot from 2004 to 2011. The epidemic started in 2004, mainly in the northern part of the vineyard (Fig. 3, box b1). Two main symptomatic patches located in the southern part were recorded from 2006 onwards (Fig. 3, boxes b2 \& b3). A fourth affected area appeared in 2007 near the access path, on the eastern side of the vineyard (Fig. 3, box b4). In addition to these main diseased areas, leafroll affected many vines elsewhere in the plot. The diseased areas expanded each year and reached $86 \%$ of all vines in 2011 . The distribution of diseased vines in 2008 was mapped also on the two contiguous plots (Fig. 4). The illustration of the three plots on a single map shows clearly a continuity of the diseased areas on both sides of the study plot (Fig. 4, boxes b1 to b3). Almost all vines of the northern plot showed leafroll symptoms whereas the southern plot was less infected with two main leafroll patches. In Bonzon, the spatial dependency between symptomatic vines was significant from 2004 to 2011. The aggregation of vines showing leafroll symptoms was also confirmed statistically since the test of independence based on permutations was rejected (Fig. 6a). From 2004 to 2007, test of independence between rows showed that symptomatic vines were distributed significantly aggregated according to lines (Fig. 6b), which implies that leafroll spread from one row to the next. Then, permutation by rotation within the row proved a significant aggregation along the row from 2007 onwards (Fig. 6c), indicating a spread of leafroll along the row. The symptomatology of diseased aggregates was further analyzed with the severity scores. The test of complete spatial randomness showed that symptomatic vines were distributed according to the severity scores. This consequently revealed the existence of a gradient within diseased aggregates (Fig. 6d): as leafroll spread in the plot from the bordering plots, the first diseased vines showed the most severe symptoms whereas vines infected later showed milder symptoms. This finding was supported by the spatial analysis of the newly diseased vines of each year. The test proved a significant spatial dependency between vines showing leafroll for the first time from 2007 onwards (Fig. 6e). This analysis implies that, each year, new leafroll symptoms spread from aggregates of diseased vines. An additional permutation 
Fig. 3 Maps of the spatial distribution of leafroll in Bonzon plot between 2004 and 2011. Each square represents a vine with its disease status: symptomless (white), symptomatic (red). Boxes "bl" to " $b 4$ " indicate the disease patches appearing
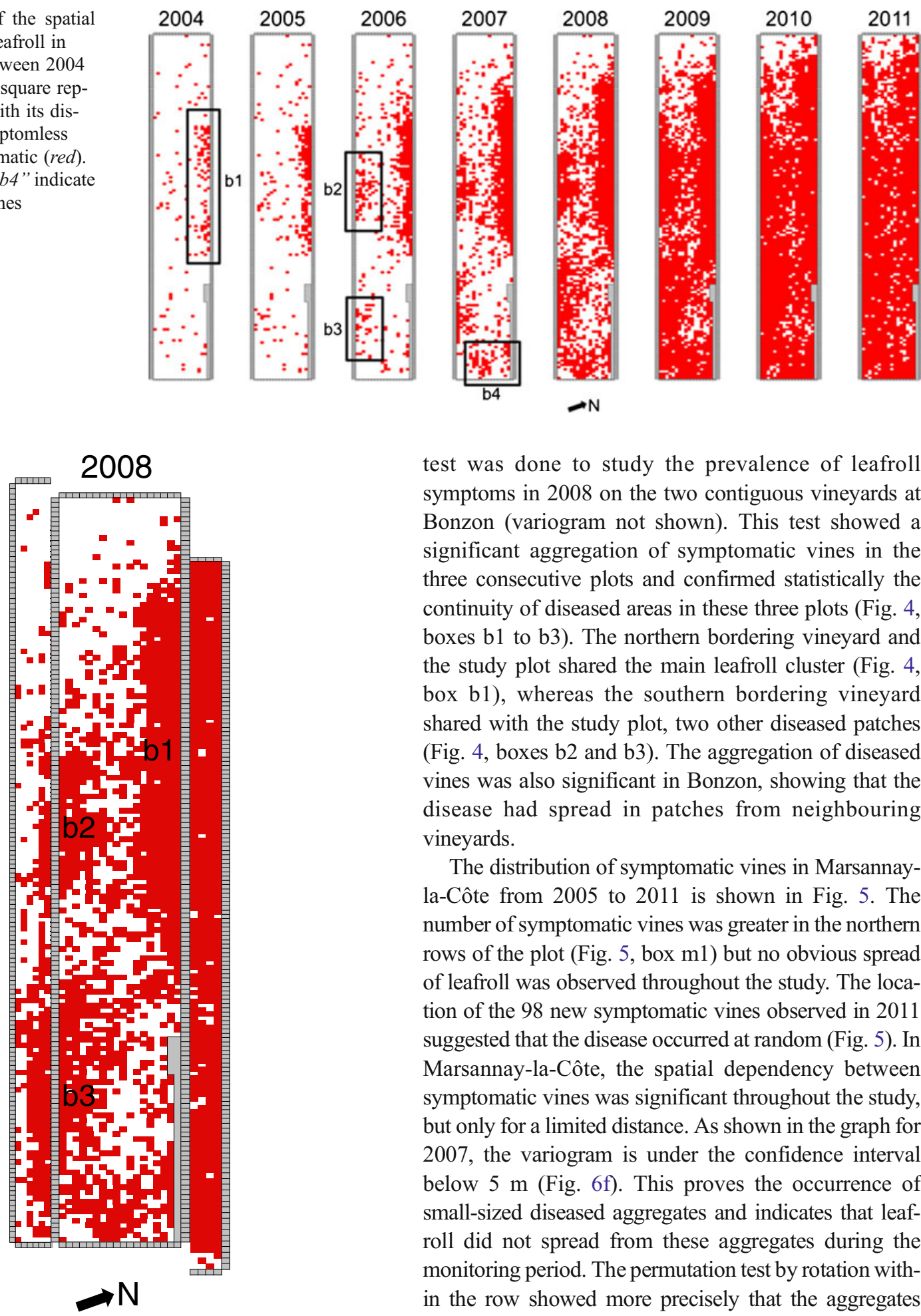

Fig. 4 Map of the spatial distribution of leafroll in 2008 in Bonzon and its two adjacent plots. Each square represents a vine with its disease status: symptomless (white), symptomatic (red). Boxes " $b 1$ " to " $b 3$ " indicate the shared diseased areas across the plots test was done to study the prevalence of leafroll symptoms in 2008 on the two contiguous vineyards at Bonzon (variogram not shown). This test showed a significant aggregation of symptomatic vines in the three consecutive plots and confirmed statistically the continuity of diseased areas in these three plots (Fig. 4, boxes b1 to b3). The northern bordering vineyard and the study plot shared the main leafroll cluster (Fig. 4, box b1), whereas the southern bordering vineyard shared with the study plot, two other diseased patches (Fig. 4, boxes b2 and b3). The aggregation of diseased vines was also significant in Bonzon, showing that the disease had spread in patches from neighbouring vineyards.

The distribution of symptomatic vines in Marsannayla-Côte from 2005 to 2011 is shown in Fig. 5. The number of symptomatic vines was greater in the northern rows of the plot (Fig. 5, box m1) but no obvious spread of leafroll was observed throughout the study. The location of the 98 new symptomatic vines observed in 2011 suggested that the disease occurred at random (Fig. 5). In Marsannay-la-Côte, the spatial dependency between symptomatic vines was significant throughout the study, but only for a limited distance. As shown in the graph for 2007, the variogram is under the confidence interval below $5 \mathrm{~m}$ (Fig. 6f). This proves the occurrence of small-sized diseased aggregates and indicates that leafroll did not spread from these aggregates during the monitoring period. The permutation test by rotation within the row showed more precisely that the aggregates were directed along the rows (Fig. 6g). Finally, global permutations performed on newly diseased vines did not show any specific distribution pattern of vines expressing leafroll for the first time, particularly for the new 


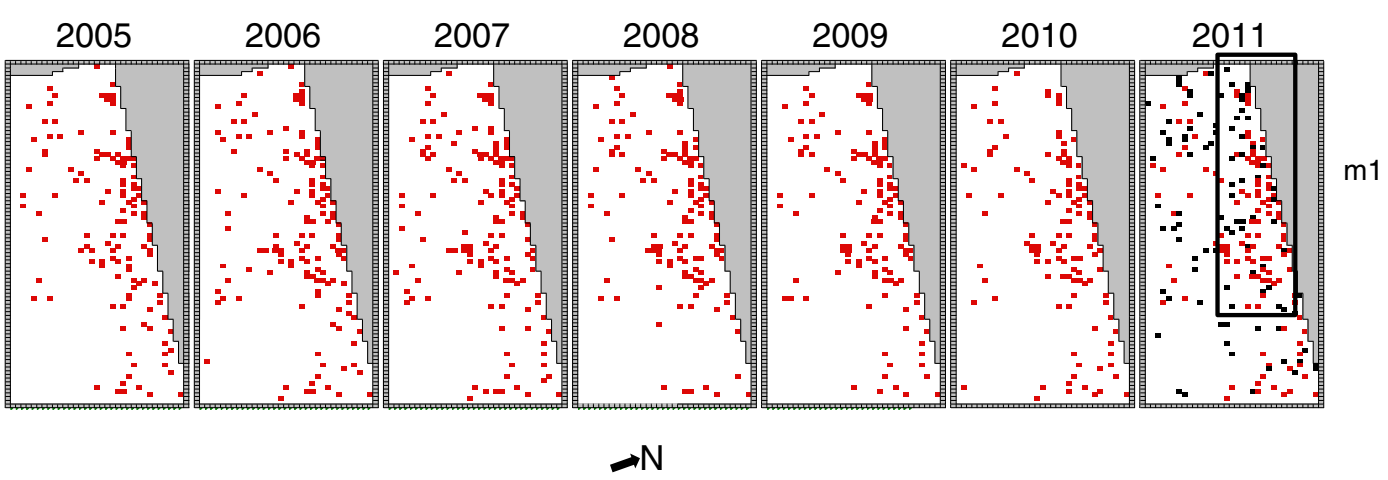

Fig. 5 Maps of the spatial distribution of leafroll in the Marsannay-la-Côte plot between 2005 and 2011. Each square represents a vine with its disease status: symptomless (white),

symptomatic vines in 2011 (Fig. 6h). Thus, the incidence of leafroll in Marsannay-la-Côte is characterized by a random distribution of the new symptomatic vines.

\section{Analysis of mealybug-infested vines distribution}

At both study sites, previous statistical analysis showed the aggregated patterns of $P$. aceris infestation (Le Maguet et al. 2010). In Marsannay-la-Côte, the clustering of infested vines was observed from 2007 to 2009 in the western part of the plot (3D diagrams available in electronic supplementary material). Phenacoccus aceris was widespread in Bonzon, particularly in four areas along the edges of the plot, which suggests that insects moved from the contiguous plots. The main aggregate of infested vines was located along the northern part of the vineyard. The mealybug infestation was also large along the southern border of the vineyard) and near the access path of the plot. The population level of $P$. aceris in the main aggregate was stable throughout the survey.

\section{Correlation between leafroll symptoms and mealybug distribution}

In Bonzon, the spatial dependency between aggregates of symptomatic vines and mealybug-infested vines was significant every year. As shown in 2007, the covariogram was outside the confidence interval above a distance of $5 \mathrm{~m}$ (Fig. 6i). Below this threshold, the aggregates are too small to be significantly correlated. The spatial dependency shown in Bonzon proved a correlation of infected vine patches with aggregates of vines infested by $P$. aceris. In Marsannay-la-Côte, the symptomatic $(\mathrm{red})$. New symptomatic vines observed in 2011 compared to 2010 are shown in black. Box " $m 1$ " indicates the area with the highest density of diseased vines

covariogram shows no significant spatial dependency between the two patterns (Fig. 6j). Thus, there was no spatial correlation between the location of vines showing leafroll symptoms and the presence of crawlers of $P$. aceris in this plot.

\section{Discussion}

Leafroll spread patterns were studied in two diseased vineyards where both leafroll disease and mealybug vectors occurred. This work is the first demonstration of a rapid natural spread of GLRaV-1 in Europe and shows for the first time that the almost all viral infections of a Pinot noir vineyard within 8 years could be attributed to the mealybug $P$. aceris.

Fig. 6 Variograms (a to $\mathbf{h}$ ) and covariograms (i and $\mathbf{j}$ ) generated by permutation tests. A spatial dependancy among data is proven when the variogram or the covariogram (continuous line) is outstide the confidence interval (dashed lines). X-axis: distance in m; Y-axis: value of the variogram or covariogram; a Test of total independance on leafroll distribution in 2007 at Bonzon; b Test of independence of rows on leafroll distribution in 2005 at Bonzon; c Test of independence within rows on leafroll distribution in 2008 at Bonzon; d Test of total independence within disease aggregates in 2007 at Bonzon; e Test of total independence on newly diseased vines in 2007 at Bonzon; f Test of total independence on leafroll distribution in 2007 at Marsannay-laCôte; $\mathbf{g}$ Test of independence within rows on leafroll distribution in 2007 at Marsannay-la-Côte; $\mathbf{h}$ Test of total independence on newly diseased vines in 2007 at Marsannay-la-Côte; i Test of total independence between leafroll and Phenacoccus aceris distributions in 2007 at Bonzon; $\mathbf{j}$ Test of total independence between leafroll and $P$. aceris distributions in 2011 at Marsannay-la-Côte 
a

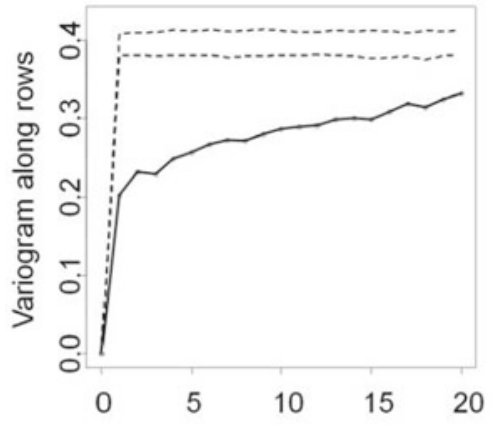

d

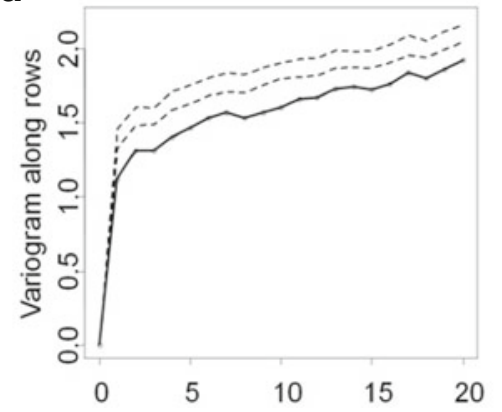

f

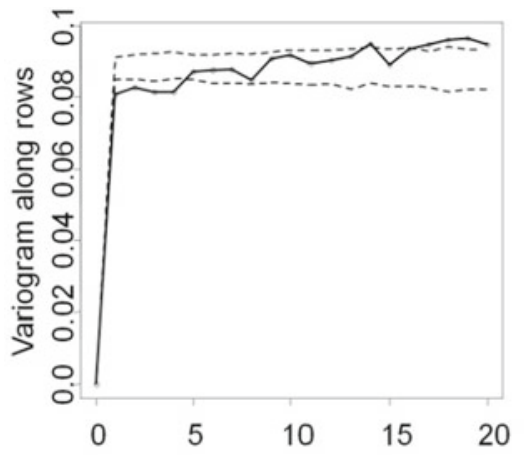

i

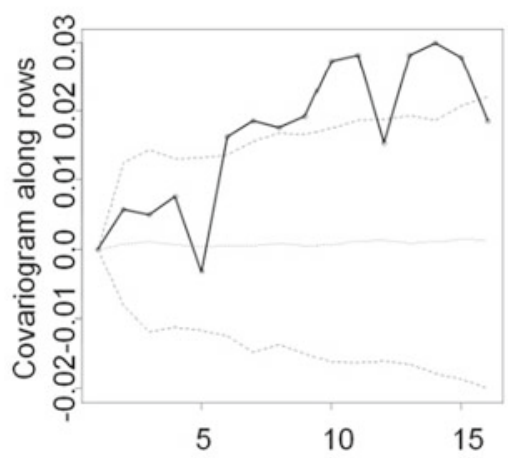

b

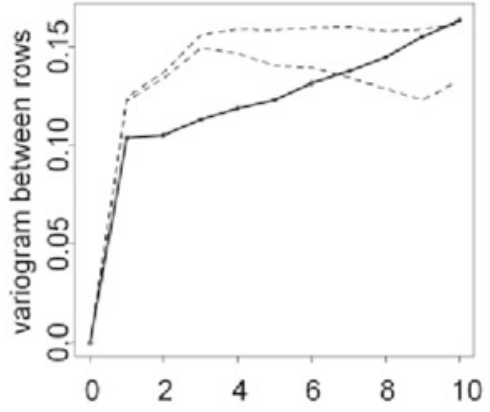

e

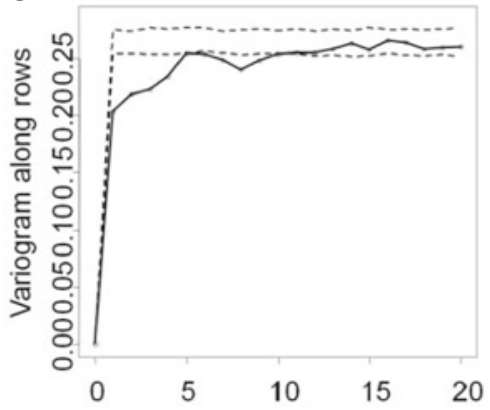

g

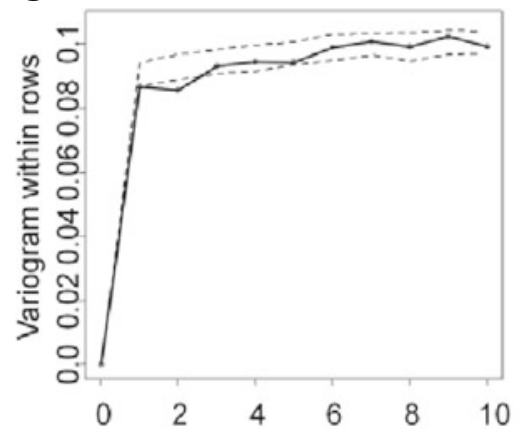

$\mathbf{h}$
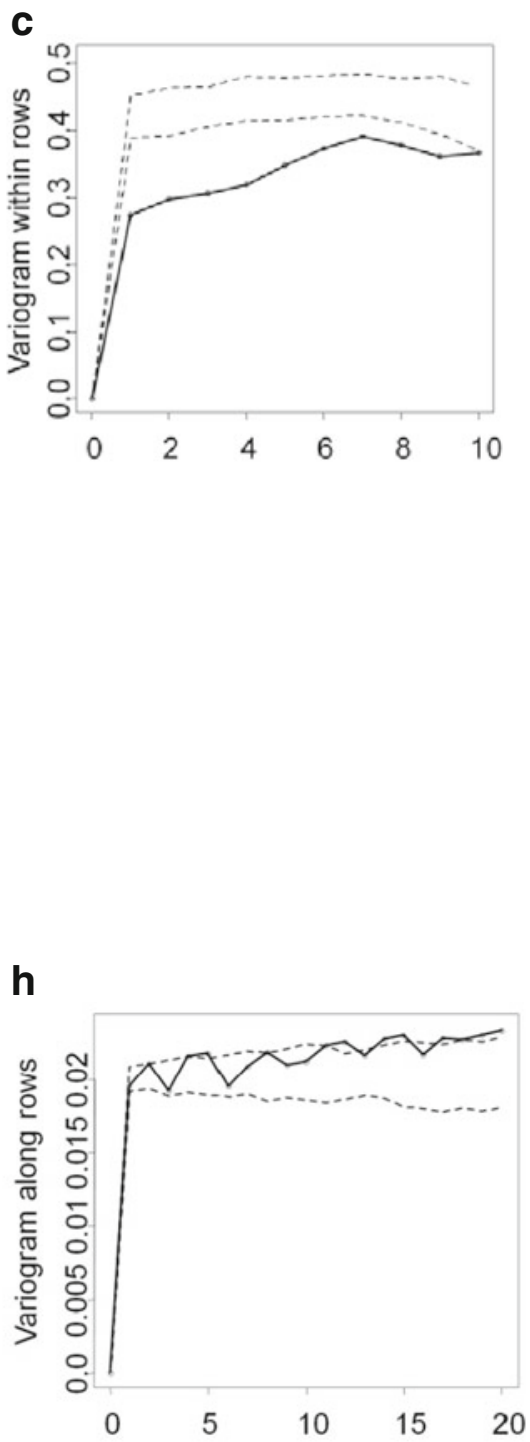

j

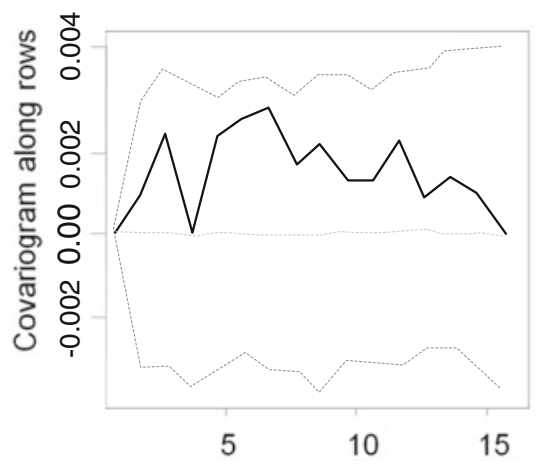

In recent years, several approaches have been used and scale insect prevalence (Charles et al. 2009; Fuchs to study leafroll spread, such as surveys on GLRaVs et al. 2009; Bertin et al. 2010), spatio-temporal 
analysis of leafroll spread in a plot (Habili and Nutter 1997; Cabaleiro et al. 2008), and analysis of the incidence of GLRaV-3 variants (Jooste et al. 2011). In previous studies, scale insects were associated with leafroll spread but without statistical correlation evidence. One of the novel findings of this work is also the spatial correlation of leafroll presence and its natural vector, proven by statistical test.

Both survey sites were affected by the GLRaV-1/P. aceris pathosystem but were planted near older vineyards that harboured different viral inoculum and mealybug infestations. These differences resulted in two distinct patterns of leafroll spread in each vineyard during the following years. At Bonzon, virus inoculum and mealybugs were highly prevalent in the vicinity: leafroll disease spread also quickly within 8 years over the whole plot from patches which first appeared on the edges of the plot. No obvious disease diffusion was noticed in Marsannay-la-Côte where there were few infected source plants and low mealybug populations. The two sites illustrate the patterns described recently (Cabaleiro 2009): high leafroll incidence due to rapid disease spread from a bordering infected vineyard in Bonzon vs. low incidence of the disease with symptomatic vines randomly distributed in Marsannay-la-Côte.

In Bonzon village, the incidence of GLRaV-1 was extremely high in the immediately neighbouring vineyards of the study plot (data not shown). The combination of leafroll spread mapping and permutation analysis on the three consecutive plots confirmed that the Bonzon plot was directly contaminated from the two contiguous vineyards. A similar contamination pattern has been reported in surveys performed on GLRaV-3 in vineyards in California (Golino et al. 2008) and Spain (Cabaleiro et al. 2008). The extension of leafroll patches in Bonzon implied that a vector with a limited dispersive ability played a major role in the contamination of the plot. The 4-year monitoring showed that $P$. aceris directly moved into the Bonzon plot from older infected neighbouring vineyards and then spread leafroll from one row to the next and also along the rows. Thus, the gradual spread of the disease in Bonzon coincides well with the known dispersal characteristics of mealybugs (Charles et al. 2009), and was confirmed by the statistical correlation of aggregates of diseased vines with mealybug distribution. Immature crawlers are mainly responsible for the dispersal of mealybugs because of their high activity and may also be the main stages responsible for leafroll spread from plant to plant (Tsai et al. 2008). Furthermore, the efficient vector capability of $P$. aceris crawlers has been demonstrated recently in controlled conditions (Le Maguet et al. 2012). However, for practical reasons, surveys of $P$. aceris were conducted in Bonzon on adult female stages. Therefore, the notation grids reflected the distribution of mealybugs at a specific time. The abundance of mealybugs may thus have been underestimated, but since no expansion of mealybug patches was shown during the 4-year survey, we can consider that the investigation on adult females gave a representative picture of $P$. aceris distribution.

The reason why the mealybug patches did not spread more in the Bonzon plot is not known. Environmental factors shape the spatial distribution of invertebrates, especially for insects of limited mobility like mealybugs (Nestel et al. 1995). Natural enemies or mutualistic insects, such as ants, may have regulated and influenced the $P$. aceris dispersal behaviour. Mealybugs produce a substantial amount of honeydew, and maintain thereby preferential relationships with different ant species (Gullan and Kosztarab 1997). For other mealybugvectored viral diseases, a close relationship between the ant-mealybug mutualism and disease spread has been suspected for cacao swollen shoot (Lockhart and Sachey 2001) and shown for pineapple mealybug wilt disease (PMWD) (Jahn et al. 2003). PMWD can indeed be disseminated among pineapple plants through the transportation of mealybug-vector by different ant species. As it was previously shown in Bonzon (Le Maguet et al. 2010) and in other vineyards in Burgundy (Sforza et al. 2003), P. aceris colonies cohabited regularly with ants. It can therefore be hypothesized that the presence of ants in Bonzon was a significant factor affecting the infestation by $P$. aceris, and thereby the spread of leafroll disease.

The spatial pattern of leafroll contamination in Bonzon suggests that viruliferous mealybugs were introduced from neighbouring vineyards at two levels. Over short distances, mealybugs could have moved by walking or were transported through ant attendance, explaining the occurrence of leafroll patches near the boundaries of the plot. Over longer distances, the small $500 \mu \mathrm{m}$ long first instar of the mealybug could have been dispersed easily by wind or carried by vineyard machinery (Grasswitz and James 2008), explaining the random distribution of some new diseased vines.

In Marsannay-la-Côte, the prevalence of leafroll in the neighbouring vineyards was very low compared to Bonzon. Furthermore, the disease expression in the 
study plot was erratic with some symptoms disappearing on diseased plants in some years. Both levels of viral inoculum and mealybug vectors were too low to induce any spread of leafroll disease. The spatial analysis showed no gradient towards neighbouring vineyards and the few infected plants present were rather distributed as small aggregates along the rows. It also seems obvious that diseased vines coming from the nursery had been planted in the Marsannay-la-Côte plot. The planting of these vines side by side in the row, groups of vines originating from the vegetative multiplication of the same mother plant: diseased replicates were planted by siblings, and this disposition was pointed out by the permutation analysis. A similar situation was described previously in a South African vineyard, where infected vines were spatially associated with specific rootstocks or scion clones (Pietersen 2006). The incidence of leafroll in Marsannay-la-Côte increased by about $5 \%$ in 2011 , revealing a potential natural spread by mealybugs from infected vines. This possible leafroll spread warrants continued leafroll and mealybug monitoring on this plot.

We proved that the almost complete contamination of a vineyard within 10 years after planting could be attributed to $P$. aceris. At Bonzon, the annual infection rate of 0.74 logit units showed that the spread was twice as rapid as previously shown in another 'Pinot noir' plot recorded in Australia (Habili and Nutter 1997). However, spread in Bonzon was similar to that estimated in Spain in an 'Albariño' vineyard infested by Planococcus citri, where GLRaV-3 prevalence reached $86 \%$ within 7 years (Cabaleiro and Segura 2006). Events of leafroll spread in mild climate regions have been mainly reported on GLRaV-3, with Planococcus sp.-infested vineyards. However, our work on the P. aceris/ GLRaV-1 pathosystem could induce a serious leafroll epidemic. Furthermore, recent experiments have demonstrated that $P$. aceris efficiently transmits six distinct GLRaV species, Grapevine virus A and Grapevine virus $B$ (GVA and GVB) (Le Maguet et al. 2012). The tolerance of $P$. aceris to low winter temperatures implies the need to give more attention to its occurrence in vineyards grown in temperate regions, notably in North America, Central Europe and Japan.

The ampelovirus GLRaV-1 is widespread in vineyards in many parts the world but its natural diffusion has only been reported on a rootstock nursery vineyard in New Zealand (Bonfiglioli et al. 2001). Our study demonstrates for the first time in Europe the major role of a mealybug in the natural spread of GLRaV-1 in a vineyard. The latency period of 2 years before GLRaV-1 detection and symptoms expression in Bonzon is consistent with previous results obtained for GLRaV-3 (Cabaleiro et al. 2008) but a substantial number of diseased vines could remain longer symptomless, particularly in Marsannay-la-Côte. Both vineyards were planted with similar clones and rootstocks and share a comparable semi-continental climate. The presence of specific GLRaV-1 isolates in Marsannay-la-Côte could explain the erratic symptomatology of leafroll in this vineyard as compared to Bonzon. A preliminary molecular analysis of the genetic diversity of GLRaV-1 isolates in Bonzon suggested that high variability of GLRaV-1 within a contaminated patch. Similarly, in a South African vineyard, virus GLRaV-3 has been proved to occur as specific variants in a single plot and to spread to adjacent vines according to infection clusters (Jooste and Goszczynski 2005; Jooste et al. 2011). The two different epidemiological patterns described in our study also represent a unique opportunity to perform further studies on the comparative diversity in GLRaV-1 isolates within and between the two study sites.

Acknowledgments We thank Dr. Boudon-Padieu, Mr. Dureuil, and the winegrowers of Bonzon and Marsannay-laCôte, Mr. Barraud and Mr. Charlopin for having initiated the leafroll survey. We are most grateful to Dr. René Sforza for his critical reading of the manuscript. This research was financed by three French professional committees for viticulture: Comité Interprofessionnel du Vin de Champagne, Epernay; Bureau Interprofessionnel des Vins de Bourgogne, Beaune; and Comité Interprofessionnel des Vins d'Alsace, Colmar; and by FranceAgriMer grants $\left(\mathrm{N}^{\circ} 200947005\right.$ 104, $\mathrm{N}^{\circ} 200977030104$ and $\mathrm{N}^{\circ}$ $20110106001104)$.

\section{References}

Al Rwahnih, M., Dolja, V. V., Daubert, S., Koonin, E. V., \& Rowhani, A. (2012). Genomic and biological analysis of Grapevine leafroll-associated virus 7 reveals a possible new genus within the family Closteroviridae. Virus Research, 163, 302-309.

Atallah, S. S., Gomez, M. I., Fuchs, M., \& Martinson, T. E. (2012). Economic impact of Grapevine leafroll disease on Vitis vinifera cv. Carbenet franc in Finger Lakes vineyards of New York. American Journal of Enology and Viticulture, 63, 73-79.

Belli, G., Fortusini, A., Casati, P., Belli, L., Bianco, P. A., \& Prati, S. (1994). Transmission of a grapevine leafroll associated closterovirus by the scale insect Pulvinaria vitis L. Rivista di Patologia Vegetale, 4, 105-108. 
Bertamini, M., Muthuchelian, K., \& Nedunchezhian, N. (2004). Effect of Grapevine Leafroll on the Photosynthesis of Field Grown Grapevine Plants (Vitis vinifera L. cv. Lagrein). Journal of Phytopatholology, 152, 145-152.

Bertin, S., Cavalieri, V., Graziano, C., \& Bosco, D. (2010). Survey of mealybug (Hemiptera: Pseudococcidae) vectors of Ampelovirus and Vitivirus in vineyards of northwestern Italy. Phytoparasitica, 38, 401-409.

Bonfiglioli, R. G. E., Hoskins, N., \& Edwards, F. (2001). Grapevine leafroll viruses in New Zealand viticulture. Riversun Technical Bulletin, 1-8.

Boudon-Padieu, E., Ridé, M., \& Walter, B. (2000). L'enroulement viral. (In Féret (Ed.), Maladies à virus, bactéries et phytoplasmes de la Vigne, pp. 47-55, Bordeaux.

Cabaleiro, C. (2009). Current advances in the epidemiology of grapevine leafroll disease. Proceedings of the 16th meeting of the International Council for the study of Virus and virus-like diseases of the Grapevine, Dijon, France, pp. 264-268.

Cabaleiro, C., \& Segura, A. (1997). Some characteristics of the transmission of grapevine leafroll associated virus 3 by Planococcus citri Risso. European Journal of Plant Pathology, 103, 373-378.

Cabaleiro, C., \& Segura, A. (2006). Temporal analysis of grapevine leafroll associated virus 3 epidemics. European Journal of Plant Pathology, 114, 441-446.

Cabaleiro, C., Couceiro, C., Pereira, S., Cid, M., Barrasa, M., \& Segura, A. (2008). Spatial analysis of epidemics of Grapevine leafroll associated virus-3. European Journal of Plant Pathology, 121, 121-130.

Charles, J. G., Froud, K. J., van den Brink, R., \& Allan, D. J. (2009). Mealybugs and the spread of grapevine leafrollassociated virus 3 (GLRaV-3) in a New Zealand vineyard. Australasian Plant Pathology, 38, 576-583.

Dimitrijevic, B. (1973). Some observations on natural spread of Grapevine Leafroll disease in Yugoslavia. Rivista di Pathologia Vegetale, 9, 114-119.

Engelbrecht, D. J., \& Kasdorf, G. G. F. (1985). Association of a closterovirus with grapevines indexing positive for grapevine leafroll disease and evidence for its natural spread in grapevine. Phytopathologia Mediterranea, 24, 101-105.

Engelbrecht, D. J., \& Kasdorf, G. G. F. (1990). Transmission of grapevine leafroll disease and associated closteroviruses by the vine mealybug, Planococcus ficus. Phytophylactica, 22, 341-346.

Fortusini, A., Scattini, G., Prati, S., Cinquanta, S., \& Belli, G. (1997). Transmission of Grapevine leafroll virus 1 (GLRaV1) and Grapevine virus A (GVA) by scale insects. Proceedings of the 12th meeting of the International Council for the study of Virus and virus-like diseases of the Grapevine, Lisbon, Portugal.

Fuchs, M., Martinson, T. E., Loeb, G. M., \& Hoch, H. C. (2009). Survey for the three major leafroll diseaseassociated viruses in Finger Lakes vineyars in New York. Plant Disease, 93, 395-401.

Gaetan, C., \& Guyon, X. (2008). Statistics for spatial models. In Springer (Ed.), Spatial statistics and modeling, pp. 320.

Golino, D. A., Weber, E., Sim, S. T., \& Rowhani, A. (2008). Leafroll disease is spreading rapidly in Napa Valley vineyard. California Agriculture, 62, 156-160.

Grasswitz, T. R., \& James, D. G. (2008). Movement of grape mealybug, Pseudococcus maritimus, on and between host plants. Entomologia Experimentalis et Applicata, 129, 268-275.

Gullan, P., \& Kosztarab, M. (1997). Adaptations in scale insects. Annual Review of Entomology, 42, 23-50.

Habili, N., \& Nutter, F. W. (1997). Temporal and spatial analysis of grapevine leafroll-associated virus 3 in Pinot Noir grapevines in Australia. Plant Disease, 81, 625-628.

Habili, N., Randles, I. J. W., \& Rowhani, A. (2003). Evidence for the apparent spread of grapevine virus and grapevine leafroll associated virus 9 in research vineyard in Australia. Proceedings of the 14th meeting of the International Council for the study of Virus and virus-like diseases of the Grapevine, Locorotondo, Italy, pp. 213.

Jahn, G. C., Beardsley, J. W., \& Gonzales-Hernandez, H. (2003). A review of the association of ants with mealybug wilt disease of pineapple. Proceedings of the Hawaiian Entomology Society, 36, 9-28.

Jooste, A. E. C., \& Goszczynski, D. E. (2005). Single-strand conformation polymorphism (SSCP), cloning and sequencing reveals two major groups of divergent molecular variants of grapevine leafroll-associated virus 3 (GLRaV-3). Vitis, 44, 39-43.

Jooste, A. E. C., Pietersen, G., \& Burger, J. T. (2011). Distribution of grapevine leafroll associated virus-3 variants in South African vineyards. European Journal of Plant Pathology, 131, 371-381.

Komar, V., Vigne, E., Demangeat, G., Lemaire, O., \& Fuchs, M. (2010). Comparative Performance of Virus-Infected Vitis vinifera cv. Savagnin rose Grafted onto Three Rootstocks. American Journal of Enology and Viticulture, 61, 68-73.

Le Maguet, J., Herrbach, E., Hommay, G., Beuve, M., \& Lemaire, O. (2010). The apple mealybug, Phenacoccus aceris is a vector of several grapevine-infecting viruses. Proceedings of the 12th International Symposium of Scale insect Studies, Chania, Greece, pp. 18.

Le Maguet, J., Beuve, M., Herrbach, E., \& Lemaire, O. (2012). Transmission of six ampeloviruses and two vitiviruses to grapevine by Phenacoccus aceris. Phytopathology, 102, 717-723.

Lee, J., \& Martin, R. R. (2009). Influence of grapevine leafroll associated viruses (GLRaV-2 and -3) on the fruit composition of Oregon Vitis vinifera L. cv. Pinot noir: Phenolics. Food Chemistry, 112, 889-896.

Lockhart, B. E., \& Sachey, S. T. (2001). Cacao swollen shoot. In O. C. Maloy \& T. D. Murray (Eds.), Encyclopedia of plant pathology, vol. 1 (pp. 172-173). New York: John Wiley and Sons.

Mahfoudhi, N., Digiaro, M., \& Dhouibi, M. H. (2009). Transmission of grapevine leafroll viruses by Planococcus ficus (Hemiptera: Pseudococcidae) and Ceroplastes rusci (Hemiptera: Coccidae). Plant Disease, 93, 999-1002.

Martelli, G. P., \& Boudon-Padieu, E. (2006). Directory of infectious diseases of grapevine and viroses and virus-like diseases of the grapevine. In Bibliographic report 1998 2004 (Options méditerranéennes, Série B: Studies and Research, CIEHAM-IAMB), pp. 59-75.

Nestel, D., Cohen, H., Saphir, N., Klein, M., \& Mendel, Z. (1995). Spatial distribution of scale insects: comparative study using Taylor's power law. Environmental Entomolology, 24, 506-512.

Peyrard, N., Calonnec, A., Bonnot, F., \& Chadoeuf, J. (2005). Explorer un jeu de données sur grille par tests de permutation. Revue de Statistique Appliquée, 53, 59-78. 
Peyrard, N., Pellegrin, F., Chadoeuf, J., \& Nandris, D. (2006). Statistical analysis of the spatio-temporal dynamics of rubber tree (Hevea brasiliensis) trunk phloem necrosis: no evidence of pathogen transmission. Forest Pathology, 36, 360-371.

Pietersen, G. (2006). Spatio-temporal distribution dynamics of grapevine leafroll disease in western cape vineyards. Proceedings of the 15th meeting of the International Council for the study of Virus and virus-like diseases of the Grapevine, Stellenboch, South Africa, pp. 126.

R Development Core Team (2011). R: A language and environment for statistical computing. R Foundation for Statistical Computing, Vienna, Austria. http://www.R-project.org. Accessed 27 Dec 2011.

Sforza, R. (2008). Les cochenilles sur la vigne: bio-éthologie, impact agronomique, lutte et prophylaxie. In Féret (Ed.) Ravageurs de la vigne, pp. 188-210, Bordeaux.
Sforza, R., Boudon-Padieu, E., \& Greif, C. (2003). New mealybug species vectoring Grapevine leafroll associated viruses -1 and -3 (GLRaV-1 and -3). European Journal of Plant Pathology, 109, 975-981.

Tsai, C. W., Chau, J., Fernandez, L., Bosco, D., Daane, K. M., \& Almeida, R. P. P. (2008). Transmission of Grapevine leafroll-associated virus 3 by the vine mealybug (Planococcus ficus). Phytopathology, 98, 1093-1098.

Zimmermann, D., Bass, P., Legin, R., \& Walter, B. (1990). Characterization and serological detection of four closteroviruslike particles associated with leafroll disease on grapevine. Journal of Phytopathology, 130, 205-218.

Zorloni, A., Prati, S., Chiesa, S., \& Bianco, P. (2006). Transmission of Grapevine leafroll-associated virus 3 by the soft scale insect Neopulvinaria innumerabilis. Journal of Plant Pathology, 88, S61. 